\title{
Debate on the Plan of Making 'Fiqh Waria': Framing Analysis in Online Media
}

\section{Perdebatan Rencana Pembuatan 'Fikih Waria': Analisis Framing pada Media Online}

\author{
Genta Maghvira ${ }^{1}$, Lisa Mardiana ${ }^{2}$, Syukri $^{3}$ \\ ${ }^{1}$ Study Program of Communication Science, Faculty of Language and Communication \\ Science, Universitas Islam Sultan Agung, Jl. Kaligawe Raya No. KM. 4 Semarang, \\ Central Java 50112, Indonesia \\ ${ }^{2}$ Study Program of Communication Science, Faculty of Computer Science, Universitas \\ Dian Nuswantoro, Jl. Imam Bonjol No. 207, Semarang, Central Java 50131, Indonesia \\ ${ }^{3}$ Study Program of Communication Science, Faculty of Social and Political Science, \\ Universitas Muhammadiyah Makassar, Jl. Sultan Alauddin No. 259 Makassar, South \\ Sulawesi 90221, Indonesia \\ *Corresponding author, e-mail: genta@unissula.ac.id
}

\begin{abstract}
This research is an online media study about the phenomenon of 'waria' (transgender) people in Indonesia. Okezone.com reports about plans to make 'Fiqh Waria.' Fiqh is expected to be a reference for 'waria' to perform religious rituals in Islam. Islam has different laws between men and women. Research using Robert N. Entman's Framing Analysis. According to Entman, framing is a selection process that highlights aspects: problem identification, causal interpretation, moral evaluation, and action recommendations. The results of the study mentioned that in identifying the problem, it was reported about the plan to make a special jurisprudence called 'Fiqh Waria.' In causal interpretation, making fiqh is needed so that they can perform worship after gender changes. In moral evaluation, transgenders are considered to have the same right to perform worship rituals. In the recommended action, it was reported that if the fiqh would become religious jurisprudence that humanizes humans.
\end{abstract}

Keywords: Fiqh, 'Waria', Framing Analysis, Online Media.

\begin{abstract}
Abstrak
Penelitian ini merupakan studi media online mengenai fenomena orang-orang waria (transgender) di Indonesia. Okezone.com melaporkan tentang rencana membuat 'Fikih Waria.' Fikih diharapkan menjadi referensi bagi waria untuk melakukan ritual keagamaan secara Islam. Islam memiliki hukum yang berbeda antara laki-laki dan Perempuan. Penelitian menggunakan Analisis Framing Robert N. Entman. Menurut Entman, framing merupakan proses seleksi yang menyoroti aspek-aspek: identifikasi masalah, interpretasi kausal, evaluasi moral, dan rekomendasi tindakan. Hasil penelitian menyebutkan bahwa dalam identifikasi masalah, diberitakan tentang rencana pembuatan hukum khusus bernama 'Fikih Waria.' Dalam interpretasi kausal, pembuatan fikih diperlukan agar mereka dapat melakukan ibadah setelah perubahan gender. Dalam evaluasi moral, waria dianggap memiliki hak yang sama untuk melakukan ritual ibadah. Dalam rekomendasi tindakan, dilaporkan bila fikih tersebut akan menjadi yurisprudensi agama yang memanusiakan manusia.
\end{abstract}

Kata Kunci: Fikih, Waria, Analisis Framing, Media Online.

\section{Introduction}

'Waria' is a person who thinks that he trapped in a wrong body, he confuses when

Article History: Received April 22, 2019; Revised January 15, 2020; Accepted January 27, 2020; Published January 31, 2020 
dealing with some of the consequences of life, such as the procedures for worship in the religion he profess. As a gender, 'waria' have physical form of male but he belief in himself as a she. In Indonesian Dictionary, 'waria' is an acronym of 'wanita' (woman) and 'pria' (man) (Caouette \& Guyer, 2014). 'Waria' is defined as a man who behaves like a woman, and or, a man who has feeling like a woman. In more general terms, 'waria' is often referred to transgender. In the online page of Nahdlatul Ulama Organization, transgender is defined as someone who has a gender identity or gender expression that is different from his designated sex, for example a person who is biologically male more comfortable to look and behave like a woman or vice versa. Furthermore, in this paper, the 'waria' will be seen as a single community (Nahdatul Ulama, 2017).

As a personality, the presence of a 'waria' had a long process. According to Kartono (2009) personally, the emergence of 'waria' can not be separated from the strong impulses from within that their physical are not suit with psychological conditions. However, normatively societies in Indonesia do not recognize the existence of a third sex among man and woman. The 'waria' also often involved in social conflicts with various forms of abuse. Not all societies, including their own families could accept the presence of 'waria' as reasonably as any other gender. These conflicts caused their space became narrower and more isolated from the social environment, while the 'waria' were required to survive both psychologically and financially in that self-isolating environment. Then the 'waria' commonly can only do work outside formally institutions, most of them being street singers or self-employed.

From the website of ageuk.org.uk (Factsheet16, 2019), transgender (or in this case, 'waria') are people whose gender identity differs from their assigned sex. Psychically, it is undeniable that human beings have reason and desire for God, religion and prayer. The matter of religious rituals, also become a long thought for 'waria'. In rituals of worship, it is unclear that 'waria' should perform as male or female. The laws which organizing the rules of rituals in Islam is called Fiqh or 'Fikih' (Indonesian pronunciation). Generally in Islam, man and woman have different religious rules, from birth to death later.

Fiqh, etymologically close to science that explain the laws of Islamic shari'ah. Also, according to the term, fiqh is a science that explains the laws of syara' (Islamic law, the provision of Allah) which is practical that derived from the detailed Islamic-law arguments (Rasjid, 2005)

As a country with the most muslim population, the adherents of Islam in Indonesia from childhood to adulthood are taught to fiqh education in schools, in their home, and in their social environment. Man and woman are distinguished in religious activities. For example, the line of the man's prayer position is in front of the woman, the male 'awrot' is not as closed as the woman's 'awrot.' 'Awrot' is parts of human body that must be covered from the eyes of others with clothing. The male is obliged to do the Friday-prayer while the woman is not obligated, so the inheritance rights of male are different from the rights of the female heir. Also with the process of bathing the corpse, the body corpse of man must be bathed by man, and woman's body corpse must be bathed by woman. From those appeared that Islam is so orderly and detail in organizing its people. Then what about the 'waria' who are in the middle, not man in their mind and also not woman in their body?

The question has always been a debate in society itself, and it is reflected in the news. There should be a special fiqh or jurisprudence for 'waria', so that they can do rituals activity according through their religion. This study seeks to learn how the common society sees the urgency of making a fiqh for 'waria' or transgender, especially 
in the online mass media. Online media was chosen because of the rapid and widespread of information dissemination, as well as one of the most accessible media platforms.

\begin{tabular}{cccc}
\hline No. & News Title (Indonesian) & News Title (English) & Online Media \\
\hline 1. & 'Rumor Fiqih Waria, FJI & 'Rumor Fiqh Waria, FJI & Merdeka.com \\
& Ancam Segel Ponpes & Threaten to Seal of & (Kresna, 2016) \\
& Transgender Islamic & \\
Boarding School in & \\
2. $\quad$ 'Laskar FJI Mendatangi & 'Personnel of FJI & Arrahmah.com \\
& Pesantren Waria Terkait & Visited Waria Islamic & (Ameera, 2016) \\
& Penerbitan Fiqih Waria' & Boarding School & \\
& Related to Issue of Fiqh & \\
3. Buku SD Memuat Banci & 'Primary School Book & Sindonews.com \\
jadi Imam Menuai & Bring up Waria Become & (Moeslim, 2016) \\
Protes' & Imam Cause Protest' & \\
'Ponpes Al Fatah & 'Al Fatah Islamic & Iyaa.com \\
Bantah Bikin Fiqih & Boarding School Denies & (Waskita, 2016) \\
Khusus Waria' & Make a Special Fiqh for & \\
& Waria' & \\
\hline
\end{tabular}

Table 1. News Report of 'Fiqh Waria' in Online Media (source: the researchers)

This research analyzes a news in online media, reported by Okezone.com. The reasons for subject selection is determined by the way the Okezone.com reports the case differently. Other media more shows that they don't agree with the plan of making 'Figh Waria,' but Okezone.com dare to report about it from different sides. Okezone.com provides the perspective that the 'Fiqh Waria' is expected to become a reference for 'waria' in doing religious rituals.

The title of the news is 'Pembuatan Fikih Waria Bertujuan agar Mereka Bisa Beribadah (Making 'Fiqh Waria' Aims to Make Them able to Worship).' From the title it already seen that Okezone.com prefers to underline the purpose of making the 'Fiqh Waria' itself. The entire content informs that The Head of Al Fatah Islamic Boarding School Yogyakarta (further known as Islamic Boarding School for the 'waria'), Abdul Muhaimin plans to make 'Fiqh Waria.' The fiqh will discuss about the procedures of rituals-worship, the management of the corpse and the rights of inheritance. Abdul Muhaimin also deplored the actions of some people that prohibit the making of it. By reading over and over again, the news takes the perspective of making a fiqh for 'waria' by the side of its positive goal, not the debate over the case.

According to Gaye Tuchman citied by Sobur (2011), the communication science, the media so far can include their perspectives in interpreting social reality. They choose to define the aspects that are highlighted or eliminated, they can determine the structure of the news according to their will, from which side the event will be highlighted, which part of the event takes precedence or forgotten, also determine who will be the informant. News is not merely a representation of events, but it also contains the media values.

According to A. M Rosenthal (Pardede, 2001) objectivity is an important part of the character of the mass media, but total objectivity may be impossible, because every news is written by a human who normally has emotion inside.

One such action is in terms of choice of title and highlighting of event area. 
Although the mass media is only reporting, but the selection of point of view, certain terms or symbols, will disturb the understanding of society. The use of certain terms has implications for the emergence of certain meanings. The way of presentation of a reality and the way reality has been constructed are also determined the meaning of the news.

To analyze the subject, the authors used framing scheme of Robert N. Entman. In communication science, framing analysis represents a tradition that uses multidisciplinary approach to analyze phenomena or communication activities. According to Anggraeni (2018), Entman Framing Analysis is also used to see the suppression of delivery criteria and presentation of what editor or journalist uses in constructing the events, framing the news and then present it, so that the news presented becomes more noticeable, meaningful and impressed the reader.

This analysis examines the strategy of selection and linking facts into a news in order to be more meaningful, more memorable, and to lead the interpretation of audience according to perspective that the media wants. In other words, framing is an approach to know how perspective is used by journalists in selecting issue and writing news. The perspective ultimately determines what fact is taken, which part is highlighted and removed, and even decides to where the news will be going. Hence, the news becomes manipulative and aims to dominate the subjects as something legitimate, objective, natural, and inevitable (Imawan, 2000)

The framing of Robert N. Entman was chosen because it has a distinctive element of analysis-scheme that is oriented towards the discovery of a problem way out. Unlike the other framing such as Gamson and Modigliani which focuses more on news package, and also it is not unlike the framing of Zongdan Pan and Kosicki that prefers to linguistic structure used by journalists in fact writing.

Robert N. Entman's framing captures two major dimensions of news: the selection of issues and the emphasis on aspects of reality. Sobur (2012) explains, these two factors can further sharpen news framing through the selection of issue that is newsworthy and emphasis content news. The perspective of the journalist will determine the facts that journalist chose, highlight, and discard. Behind all of this, the decision making on which side is highlighted necessarily involves the value and ideology of the journalists in news production process. Robert N. Entman's Framing Analysis can be seen as below:

\begin{tabular}{cc}
\hline Aspects & The Sentence of the Question \\
\hline Problem Identification & How is an event seen? \\
Causal Interpretation & Caused by what is this event? \\
Moral Evaluation & What moral value is used to legitimize an action? \\
Treatment Recommendation & What sort of solution is offered? \\
\hline
\end{tabular}

Table 2. Scheme of Robert N. Entman Framing Analysis (Sobur, 2012)

No literature review has been found on similar article that matches exactly with the topic and methodology. Therefore, the literature review in this study will discuss the major themes, like 'waria' (or transgender in general), and framing analysis methods. Here are literature reviews that successfully summarized:

First, 'Pesantren Waria dan Konstruksi Identitas (Islamic Boarding School of Waria and Construction of Identity)' (Latiefah, 2013). This article discusses how the 'waria' look at themselves through the community and how the public contrary perceives the identity of 'waria.' In reality, 'waria' still get discriminatory treatment because their identity is seen as an aberration. This view results the placement of 'waria' as marginalized. Most people could not accept the identity of 'waria.' Then some 'waria' do various ways to be accepted by society, one of them is going to an Islamic Boarding 
School. Islamic Boarding School as a tool to reconstruct the identity of 'waria' where provide a picture of positive image. The existence of Islamic Boarding School for 'waria' has successfully managed to reconstruct the identity of 'waria' by creating a new construction that can provide a picture to the public that 'waria' have a positive side and people believe there is difference in behavior between 'waria' who is in Islamic Boarding School and the 'waria' who does not participate Islamic Boarding School.

Second, 'Pendidikan Agama bagi 'Waria' melalui Pesantren: Kasus Pesantren Waria Al Fatah Yogyakarta (Religious Education for 'Waria' through Islamic Boarding School: The Case of Al Fatah Waria Islamic Boarding School, Yogyakarta)' (Sri Salmah, 2010). This article discusses how society has a perception that the world of 'waria' is a dark world, negative, also a disturbing environment. The people could not accept the existence of 'waria' so that never opens any opportunity, the opening of Islamic Boarding School for 'waria' could be a solution. They show how the 'waria' recited holy verses of the Quran that touching the listener's heart, they also perform the prayer, fasting, and other deeds performed. The 'ustadz' (teacher) puts 2 (two) main characteristic of Islamic Boarding School: patience and accept everything with sincerity, and diligently doing the right job. With the understanding of religion through boarding school is expected for 'waria' began to open their lives through the right path.

Third, 'Analisis Framing Pemberitaan Media Online mengenai Kasus Pedofilia di Akun Facebook (Framing Analysis on Online Media Reporting about Pedophilia Cases in Facebook Account) (Mustika, 2017). This article discusses the case against children that often happens, it makes many people realize how vulnerable children become victims of immoral crime. The subject of this research is a group account on facebook called Loli Candy's that collects pornographic photos of children. The purpose of the study was to see how online media Kompas.com and Republika Online framing about pedophilia through facebook account. The model of analysis used is Robert N. Entman Model. The result difference framing in the news raised by Kompas.com and Republika Online most often seen lies in the selection of resource persons. Republika Online as an Islamic media always chooses speakers who have Islamic thought.

\section{Method}

This research is included in the sequence of qualitative research. Qualitative study is a descriptive research and tends to use analysis with inductive approach. Process and meaning (subject perspectives) are more highlighted in qualitative study. Theoretical basis is used as a guide to focus the study in accordance with the facts in the field. In addition, the theoretical is also use to provide an overview of the study background and as a material discussion for study result.

The paradigm of this research is constructivist paradigm. The media work is essentially an activity of constructing reality. Media content is the result of media workers constructing the various realities they choose. Journalistic reports in the media are the result of the preparation of realities in a report form. Thus, as Tuchman says, news is essentially a constructed reality (Sudibyo, Hamad, \& Qodari, 2001).

As it says before, the analysis used is framing analysis of Robert N. Entman. The framing in Entman's view, consistently offers a way of expressing the 'power of a communication text.' Framing, as Entman says, includes selecting and choosing which parts of the news that are considered important for publication. Creating frames is the activity of selecting some aspects of an reality-understanding and making it more 
prominent in a text, then communicate it in such a way as to produce: (1) the problem identification; (2) causal interpretation; (3) moral evaluation and (4) treatment recommendation (Siahaan, 2001). It is hoped by this framing analysis, it can explain in appropriate way, the influence on human consciousness that is urged by the transfer of communication from a news text. In this case, the news by Okezone.com entitled 'Pembuatan Fikih 'Waria' Bertujuan agar Mereka bisa Beribadah (Making 'Fiqh Waria' aims to make Them able to Worship).'

\section{Results and Discussion}

Here is the results and discussion of the analysis that has been found on subject:

\begin{tabular}{|c|c|}
\hline Media Type & Online \\
\hline Media Name & Okezone.com \\
\hline News Title & $\begin{array}{l}\text { "Pembuatan Fikih Waria bertujuan agar Mereka bisa Beribadah } \\
\text { (Making 'Fiqh Waria' aims to Make Them able to Worship)" }\end{array}$ \\
\hline URL & $\begin{array}{l}\text { https://news.okezone.com/read/2016/03/08/510/1330795/pembuata } \\
\text { n-fikih-waria-bertujuan-agar-mereka-bisa-beribadah }\end{array}$ \\
\hline News content & $\begin{array}{l}\text { Yogyakarta -- Guaranteed freedom of worship, head of Al Fatah } \\
\text { Waria Islamic Boarding School, Abul Muhaimin discloses, there are } \\
\text { plans to make fiqh (Islamic rules and law) for 'waria.' } \\
\text { Muhaimin added that the making of the 'Fiqh Waria' is an initiative } \\
\text { of the Universitas Islam Nahdlatul Ulama (UNISNU) in Jepara City, } \\
\text { Central Java. "The plan of making the fiqh comes from UNISNU," } \\
\text { said Muhaimin at the office of LBH Yogyakarta, Tuesday } \\
(8 / 3 / 2016) \text {. } \\
\text { According to him, the making of this fiqh is necessary so that waria } \\
\text { can worship according to their belief. "They ('waria') also have the } \\
\text { right to study religion and practice worship, The fiqh that is required } \\
\text { is more like applied fiqh, a religious jurisprudence that humanize } \\
\text { humans," he said. } \\
\text { Meanwhile, a teacher of the 'waria' Islamic Boarding School, Arif } \\
\text { Nuh Safri, added that later in the fiqh, will discuss the rules of } \\
\text { worship, the management of the corpse, and the right of inheritance. } \\
\text { For that, he deplored the actions of some people who forbid the } \\
\text { making of the fiqh. "Al Fatah Islamic Boarding School activities do } \\
\text { not deviate from Islamic values," he said. }\end{array}$ \\
\hline
\end{tabular}

Table 3. Research Subject (Yuwono, 2016)

In the problem identification, the news content is the plan of making 'Fiqh Waria' by the Al Fatah Islamic Boarding School, Yogyakarta. It means the making of 'Fiqh Waria' is still a plan and there is no realization yet, so it should be no need to be worried for other who thinks that being 'waria' is wrong and unforgiveable.

In the causal interpretation, the news contents are; (1) The making of the fiqh is necessary so that 'waria' can do rituals worship according to their belief; (2) It is explained that the making of 'Fiqh Waria' is the result of an agreement with the Universitas Islam Nahdlatul Ulama (UNISNU) in Jepara City, Central Java; (3) It added a resource statement to support the previous statement: "The plan of making 'Fiqh Waria' comes from UNISNU"; and (4) The informant chosen was Abdul Muhaimin, the head of Al Fatah Islamic Boarding School. These news contents meaning are the plan of making 
'Fiqh Waria' is also plan of UNISNU, not just from Al Fatah. Be think the urgency that the 'waria' need to expression their belief in rituals worship and all religious activities.

In the moral evaluation, the news contents are; (1) The news text writes the statement of an informant who states that "Al Fatah Islamic Boarding School activities do not deviate from Islamic values"; (2) The text deliberately added with the statement of an informant that states "They ('waria') also have the rights to study religion and practice worship"; (3) The second informant chosen is Arif Nur Safri, as teacher of Al Fatah Islamic Boarding School. These news contents meaning are that the activities inside the Islamic Boarding School are ordinary. There is nothing strange. Simply just for the 'waria' can still learn their religion and do rituals worship.

In the treatment recommendation, the news contents are; (1) The selected informant statement was: "The fiqh that is required is more like applied figh, a religious jurisprudence that humanize humans"; (2) Also followed by an explanation that: "in the fiqh, it will be discussed in the manner of worship, the administration of the corpse, and the right of inheritance"; (3) The selected informant is Arif Nur Safri, as teacher of Al Fatah Islamic Boarding School. These news contents meaning are the fiqh will later become a practically applied jurisprudence. The 'waria' are also human beings equal to others, they have religious aspects (laws, rules, etcetera) from birth to death later. 'Waria' have the rights to know how they do religious activities after gender-changed.

The first 'waria' in Al Fatah Islamic Boarding School, his name is Maryani. At first, Maryani came into the boarding school and attended a recitation, and Maryani was well received by the boarding school. Then Maryani who feels waria often get a negative stigma from the community, or to be ostracized by the community, so Maryani wants to invite his fellow waria to join the worship activity. As a form of proof to the people around that waria are not identical with the prostitution and deviant behavior. Briefly, the establishment of this pesantren begins with an awareness of God's presence from humans, which in human must also be aware of their existence as a creature that has a God (Safri, 2016).

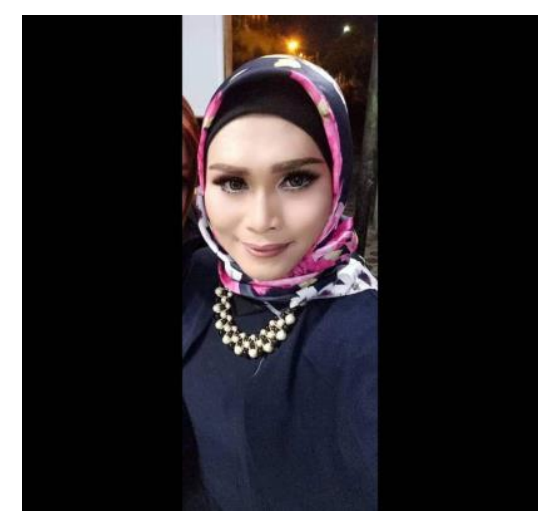

Figure 1. Our Contributor ('waria'), Natalia Nur Siska (source: authors's file)

The authors had an interview with a 'waria' named Natalia Nur Siska, he said he is desired to be able to use 'hijab' (a veil which cover the head and hair in Islamic rules for woman) and do rituals of worship like a woman. He said he usually praying in the mosque during Maghrib, using 'sarong' (a wide piece of cloth that is wear at the waist to cover the lower waist to down for man). But when praying at home, he dared to use 'mukena' (a cloth that use to cover all over woman's body parts except face and palm), he said that he did it because he wants to be honest before God, be a she as what he thinks he is. Furthermore, Natalia admitted often ventured to wear 'hijab' when in a outside his own 
environment. But when in an environment which familiar to him, he is more often dressed and performing rituals of worship like a man. The 'waria' have long been a negative stigma in society. In addition, the 'waria' is often used as a joke-figure in the mass media of Indonesia. Some television uses the 'waria' as the object of suffering and mockery in comedy programs. When a person becomes a 'waria,' the society seems to have a legality to humiliate him, laugh at him, and not to regard the personal qualities of him.

When the government shows a counter attitude to transgender, the 'waria' were also the first side to be deprived of their rights. The rights to work, the rights of acknowledgment their talents, as well as the rights to perform rituals according to their religion, are often still restricted. It can be interpreted as how low to live as a 'waria.' Society indirectly prevents all the efforts of the emergence of other identities than man and woman, in the name of the common good.

Different country might have a little different way of worshiping and everything about religion activity. From the website of New York Times, it says that in India they have Transgender Goddesses. In southern India state of Tamil Nadu, they perform Mayana Kollai Festival. It is the transformation of transgender into goddesses for an annual Hindu festival takes place in an atmosphere of reverent, somber concentration.

Behind the festival, some same thing happens just like in other country, Transgender in India leave a conservative mainstream culture for an equally conservative subculture. Some live in communes with a strict network of rules under the authority of leaders they refer to as 'mothers' and 'grandmothers.' Others live with their parents or head heterosexual families. Many reveal their identities as teenagers and are met with years of taunts, beatings and forced sex. But during the festival, which takes place in either February or March each year, these troubles are impossibly distant. Any trace of human expression is lifted. At least, they have a festival to express their identity and the way they worship based on their identity (Devanampattinam, 2016).

The 'waria' sentiment is common in Indonesia. In past decades, militant Islamists have attacked 'waria' and all LGBT public activities, in several instances breaking-up or otherwise forcing the cancellation of scheduled events. Activists say waria cannot trust police to protect them when they face such orchestrated intimidation or violence. For example the situation in Aceh province has been particularly bad. Aceh, the only Indonesian region allowed to implement full Sharia (Islamic law), prescribes 100 public lashes for people caught committing same-sex sexual acts; Acehnese officials have openly stoked anti transgender sentiment, calling 'waria' and all LGBT people in general as a threat that is encroaching on the province.

From the report of Human Right Watch, across the country prior to January 2016, many Indonesian transgender minorities lived with prejudice. Discretion purchased safety: many of them chose to live without publicly disclosing their sexual orientation or gender identity as a means to protect them from discrimination or violence. But in early 2016, the combination of government officials, militant Islamists, and mass religious groups stoking anti transgender intolerance led to immediate deterioration of the human rights of waria individuals. What began as public condemnation quickly grew into calls for criminalization and cures, laying bare the depth and breadth of officials' individual prejudices.

The transgender community is not the only minority population to have come under attack in Indonesia in recent years (Widiastuti, 2017). As documented by Indonesian rights groups, Human Rights Watch, and others, religious minority groups have experienced a steady uptick in harassment, intimidation, and violence at the hands of 
militant Islamists. The government's failure to respond decisively--in some cases actively facilitating harassment and intimidation or issuing discriminatory regulations and decrees--has left minority religious groups particularly vulnerable. A comparable failure in the face of the recent rise in anti transgender threats could have deadly consequences for 'waria' in Indonesia.

\section{Conclusion}

The right to religion is the right to express individual spirituality. This includes the right to perform religious rituals. Freedom in carrying out religious rituals for waria and or for transgender individuals here means that they have the right to carry out religious teachings that are believed and have the discretion in carrying out worship according to the religion they believe, for example: praying in congregation at the mosque and getting corpse care according to Islamic teachings. Carrying out religious rituals is a human right, and it is a freedom to practice religion in various ways is a blessing from God.

From the analysis, it can be seen how the news was framed in such a way, from the selection of title, the selection of informants who only from the side of Al Fatah Islamic Boarding School, the first party which plans to make the 'Fiqh Waria,' including by the selection statements that were said by the informants, so have the meaning according to a specific purpose.

A frame demands the attention of some aspects of reality by ignoring other elements that allow audience to have different reaction. Okezone.com frames the report of this case in terms of its utility as seen as in third paragraph (see Table 3 ) and that the fiqh will only be easy applied jurisprudence for those who have gender-changed in order to continue religious laws and rituals worship as seen as in fourth and fifth paragraphs (see Table 3).

After the analysis, it can be stated that Okezone.com provides an understanding to the society about the plan of making 'Fiqh Waria' with details by the first party, so that common people do not become worried, since the 'waria' are still considered irregularities for most people. By looking at the contents of the fiqh later, it is hoped that people will no longer protest and respect the rights of 'waria.' The 'waria' should have same rights to be able to learn their religion and to perform daily worship activities. With this news, it is expected that the protests were feared will lead to violence can be avoided. This is also the one of journalistic activity goals, which are: to provide information, to give an understanding of a phenomenon, to educate society and become a tool of social control.

From this research, we learned that there is too much confusion in a 'waria' as a person, in that confusion the public tends to make an explicit judgement of right or wrong. This in fact does not solve the problem, but instead adds psychological pressure for them. And the next paradox is that when they are psychologically depressed, like other common people, they need religious factors to support their mentality. 'Fiqh Waria' is actually considered to make it easier for them or at least give them space to pray properly.

\section{Acknowledgements}

We present this paper to our contributor, Natalia Nur Siska, a good friends of us. Hopefully Natalia Nur Siska and the others (waria) would soon get freedom of worshiping according to the gender that they feel is right. May their spirit be energy for our (researchers) next research. 


\section{References}

Ameera. (2016). Laskar FJI Mendatangi Pesantren Waria Terkait Penerbitan Fiqih Waria. Arrahmah.Com. Retrieved from https://www.arrahmah.com/2016/02/22/laskar-fjimendatangi-pesantren-waria-terkait-penerbitan-fiqih-waria/

Anggraeni, D. (2018). Entman Framing Analysis of Food Governance in Online Media. Jurnal The Messenger, 10(1), 113-123. https://doi.org/http://dx.doi.org/10.26623/themessenger.v10i1

Caouette, J. D., \& Guyer, A. E. (2014). Gaining insight into adolescent vulnerability for social anxiety from developmental cognitive neuroscience. Developmental $\begin{array}{lll}\text { Cognitive } \quad \text { Neuroscience, } & \text { 65-76. }\end{array}$ https://doi.org/https://doi.org/10.1016/j.dcn.2013.10.003

Devanampattinam. (2016). Mortal to Divine and Back: India's Transgender Goddesses. Retrieved from www.nytimes.com website: https://www.nytimes.com/2016/07/25/world/asia/india-transgender.html

Factsheet16. (2019). Transgender Issues and Later Life. Retrieved from ageuk website: https://www.ageuk.org.uk/globalassets/ageuk/documents/factsheets/fs16_transgender_issues_and_later_life_fcs.pdf

Imawan, T. (2000). Media Surabaya Mengaburkan Makna: Kasus Pemilihan Walikota. PantauSurabaya, 09.

Kartono, K. (2009). Psikologi Abnormal dan Abnormalitas Sexual. Bandung: CV Mandar Maju.

Kresna. (2016). Rumor fiqih waria, FJI ancam segel Ponpes Transgender di Yogya. Merdeka.Com. Retrieved from https://www.merdeka.com/peristiwa/rumor-fiqihwaria-fji-ancam-segel-ponpes-transgender-di-yogya.html

Latiefah, U. (2013). Pesantren Waria dan Konstruksi Identitas. Jurnal Pemikiran Sosiologi Universitas Gadjah Mada, 2(1).

Moeslim, M. (2016). Buku SD Memuat Banci Jadi Imam Menuai Protes. Sindonews. Com. Retrieved from https://daerah.sindonews.com/read/1090908/190/buku-sd-memuatbanci-jadi-imam-menuai-protes-1457266901

Mustika, R. (2017). Analisis Framing Pemberitaan Media Online Mengenai Kasus Pedofilia di Akun Facebook. Jurnal Penelitian Komunikasi, 2(2).

Nahdatul Ulama. (2017). Transgender dalam Pandangan Syariat Islam. Retrieved from Islam.nu.or.id. website: islam.nu.or.id/post/read/84392/transgender-dalampandangan-syariat-islam

Pardede, P. (2001). Dramatisasi Cukup Dominan. Jurnal Media Watch Kupas, 3(2), 1718.

Rasjid, S. (2005). Fiqh Islam: Hukum Fiqh Lengkap. Bandung: Sinar Baru Algesindo.

Safri, A. N. (2016). Penerimaan Keluarga Terhadap Waria Atau Transgender. Nizham Journal of Islamic Studies, 5(1), 27-41.

Siahaan, H. M. (2001). Pers yang Gamang: Studi Pemberitaan Jajak Pendapat Timor Timur. Jakarta: Lembaga Studi Perubahan Sosial.

Sobur, A. (2011). Psikologi Umum. Bandung: Pustaka Setia.

Sobur, A. (2012). Analisis Teks Media. Bandung: Remaja Rosdakarya.

Sudibyo, A., Hamad, I., \& Qodari, M. (2001). Kabar-Kabar Kebencian: Prasangka Agama di Media Massa. Jakarta: Institut Studi Arus Informasi.

Waskita, D. (2016). Ponpes Al Fatah Bantah Bikin Fiqih Khusus Waria. Media.Iyaa.Com. Retrieved from https://media.iyaa.com/article/2016/02/ponpes-alfatah-bantahbikin-fiqih-waria-3435639.html 
Widiastuti, R. R. K. (2017). Problem-problem Minoritas Transgender dalam Kehidupan Sosial Beragama. E-Journal UIN, 10(2), 83-110.

Yuwono, M. (2016, March). Pembuatan Fikih Waria bertujuan agar Mereka bisa Beribadah. Okezone.Com. Retrieved from https://news.okezone.com/read/2016/03/08/510/1330795/pembuatan-fikih-wariabertujuan-agar-mereka-bisa-beribadah 